\title{
Changing approaches to urban planning in an 'entrepreneurial city': the case of Dublin
}

Pauline M. MGGuirk

School of Geosciences, Discipline of Human Geography, The University of Newcastle, Callaghan, Newcastle, NSW 2303.

Email: ggpmm@cc.newcastle.edu.au

and

Andrew MacLaran, Department of Geography, Trinity College, Dublin 2 Ireland

Email: amclaran@tcd.ie 
Changing approaches to urban planning in an 'entrepreneurial city': the case of Dublin

\begin{abstract}
The paper reviews the manner in which urban planning in Dublin has changed in response to central government urban renewal initiatives and an increasing ethos of entrepreneurialism within the local authority of Dublin Corporation. The paper outlines the marginalisation of local planning functions and the undermining of planning powers through the establishment of special purpose renewal agencies. Dublin Corporation planners have consequently sought refuge in integrated micro-area planning, marking a shift in philosophy regarding the appropriate role for planning in the context of entrepreneurial governance. The paper provides an empirical account of the relationship between changing approaches to urban renewal and the evolution of local planning practice, noting the challenges and opportunities for urban planning created by altered governance structures and approaches.
\end{abstract}




\section{Introduction}

The aim of this paper is to review the way in which urban planning conducted by Dublin Corporation, the local authority with responsibility for the inner Dublin area, has been transformed in response to central government urban renewal initiatives and an increasing ethos of entrepreneurialism within the Corporation itself. Transformation has occurred in the context of the changing configuration of urban governance which has produced both challenges and potential opportunities for local government planning. The paper offers an empirical account which explores the nature of those challenges and opportunities, highlighting the advances and pitfalls inherent in planning responses to them.

The paper draws on a series of in-depth interviews carried out between 1996 and 1999 with property developers, investors and business organisations, together with senior officials from the Department of the Environment and Dublin Corporation, including members of an Inner City Development Team and representatives from the departments of Planning, Development and Architecture. These, together with available documentary evidence, reports and plans are used to construct a review of the manner in which the traditional urban planning functions of the Corporation were effectively marginalised during the late 1980s from the implementation of central government urban renewal programmes. Simultaneously, its planning powers were directly undermined through the establishment of special purpose renewal agencies. In response, Corporation planners have increasingly sought refuge in micro-area planning. This draws upon the legitimacy of community-based needs by forging outcomes-oriented holistic integrated area plans for economic, social and environmental improvement to be implemented in entrepreneurial partnership with the business and community sectors. This change in approach involves explicit attempts to re-empower local government planning. Yet its micro-scale focus and reliance on private sector partnership involves inherent constraints. Clearly, the role and function of local government planning for inner Dublin is in flux. Decisions on its future direction will need to be informed by critical review of the challenges and opportunities presented by this context and a consideration of the impacts, 
at a local and metropolitan scale, of planning responses. This paper provides such a review.

\section{Background}

During the 1980s in the United Kingdom and the Republic of Ireland, property-based regeneration strategies dominated urban renewal policies (M- Guirk, 2000; Turok, 1992). The institutional and political contexts for such policies were associated with growing entrepreneurialism in urban governance which was largely orchestrated by central government initiatives ( $\mathrm{M}^{\mathrm{c}}$ Guirk, 1994; Stoker and Young, 1993). This engagement with entrepreneurial styles of governance has involved adaptations in the modes and instruments of regulation, the re-distribution of responsibilities across spheres of government, the community and the private sector, in addition to significant shifts in the cultures of interaction between them (Painter, 1997). Such modes of entrepreneurial urban governance are structured increasingly by organisational forms which involve negotiative networks stretching across government departments, quasi-government organisations, private sector and 'third-sector' interests. The politics of local government and the role of urban planning within this institutional setting have been the target of some valuable analysis (e.g. Brindley et al, 1996; Newman and Thornley, 1996), which identifies the challenges and opportunities posed by changing modes of governance for local government in general, and for local government planning in particular.

Much of this analysis has considered the 'creeping enfeeblement' (Peck and Tickell, 1994) of local government resulting from the governance regimes characterised by public/private partnerships, appointed quangos, alliances with non-government actors, and entrepreneurial initiatives, frequently involving property-led regeneration (Edwards, 1997; Lovering, 1995; Newman and Thornley, 1997; Wilks-Heeg, 1996). Analysts are careful to emphasise how, in this configuration of governance, the context for urban planning is altered. The increased privatism of entrepreneurial governance (Barnekov et al, 1989) escalates demands to meet the aims of economic and financial interests. This is especially the case where area-based special-purpose authorities are created to oversee re/development (Malone, 1996). Local government planning functions may be by-passed, 
with planning functions becoming vested in alternative, often centralised or quasi-private, agencies. This can result in a significant weakening of local influence (Winter and Brooke, 1993). Indeed, planning functions may be scattered across a range of area-based development agencies, which can create an absence of strategic spatial planning (e.g. see Newman and Thornley, 1997).

In such scenarios, urban planning can appear to become a depoliticised form of development planning which is locked into a pro-growth agenda. Broader social, cultural and environmental objectives can become residualised or diluted as they tend to be overridden by a centralised agenda of competition, growth and entrepreneurialism (Imrie and Thomas, 1995; Stewart, 1994; Peck, 1995). In planning systems like those of the UK and the Republic of Ireland, which are characterised by the distinctiveness of planning policy and development control functions, a further consequence may be a reinforcement of existing divisions between the formal planning system and those social issues embodied in other government programmes (Newman and Thornley, 1996).

However, a growing body of literature has emerged (e.g. Imrie and Thomas, 1993; Mayer, 1994; Charlesworth and Cochrane, 1994; Healey, 1995; Bassett, 1996) which points to the possibilities for local government, and therefore also for local government planning, to exploit opportunities which are presented by this new context. Although highly centralised, this is a context which operates in a fluid mode of operation in which boundaries between the public, private and community sectors become blurred. Its functioning relies on negotiative networks of resource dependency rather than on hierarchically determined bureaucracies (Rhodes, 1988). Thus, despite the tendency for local governments to be disempowered by entrepreneurial systems of urban governance, it is suggested that the new institutional forms and channels of communication of urban governance actually present opportunities which might be exploited to the advantage of local governments. By bringing their abilities to act as mediators and catalysts into a context dominated by central government urban policy initiatives, well-directed opportunism might allow planners to become more central to the process of policy making and plan implementation through their unique possession of strategic overview 
together with local expertise and sensitivity to local interests (Cochrane, 1991; Stoker and Young, 1993). These capacities might enable local government planners to mobilise effective networks which could work in an integrated fashion towards achieving broad environmental, economic, social and cultural planning aims. For example, Stoker and Young (1993) have argued that local government and local government planners could become significant contributors to tackling urban problems if they could develop a new style of operation which is amenable to contemporary modes of governance. This would require a departure from hierarchical and bureaucratically-determined practices that are driven by rules and regulations and which are slow to respond to new demands arising from altered policy and socio-economic environments.

While such a shift in operations may seem to offer the opportunity to become more closely involved in key decision-making processes, this potential may be rather more apparent than real. Because the greater part of development activity is led by the private sector and remains dependent on its profitability criteria, such a reliance inevitably emphasises the imperative of maintaining a corporate ethos and adopting modes of planning practice which continue to be appropriately supportive of property capital (Leitner and Garner, 1993; Stewart, 1994; Wilks-Heeg, 1996). Moreover, the tendency to adopt such partnership-based approaches within only small districts means that the strategic element of such empowerment is absent. In Dublin, the very recent adoption within local government planning of entrepreneurial and holistic micro-area planning strategies presents planners with both the opportunities and the constraints of new modes of urban governance. Thus, a review of the evolution of this planning response and a consideration of its potential is timely.

\section{Dublin: the context for planning}

As the largest city in the state, the seat of national government, and with a population of over one million persons, Dublin has almost inevitably attracted the interest of central government Ministries and national politicians. The task of inner-city renewal, where in 1986 there existed some 600 cleared sites and derelict buildings comprising a combined area of 65 ha., was considered to lie beyond the scope of local authority renowned for 
bureaucratic inertia and failure adequately to co-ordinate functions which were fragmented over numerous local government departments ( $\mathrm{M}^{\mathrm{c}} \mathrm{G}$ irk, 1994). Thus, a continuing and varied range of interventions concerning inner city renewal has resulted from central state disaffection with its local administrations. More generally, such interventions reflected a structural relationship between central and local states in Ireland in which the decentralisation of policy-making is very limited, the roles of local government being narrowly prescribed and limited in comparison with most European countries. Indeed, it can be argued that municipal government in Ireland commonly amounts to little more than local management of policies which are determined nationally (MacLaran, 1993; Goldsmith and Klausen, 1997).

The administrative arrangements for Irish local government have long been based on the twin elements of the elected members and a chief executive, known as the manager, who is a professional administrator. The administrative structure designates certain local authority matters as "reserved functions" of the elected members, including those which relate to the adoption and alteration of development plans-strategic planning policy documents nominally produced at five-yearly intervals. Councillors are also empowered to revoke or modify a permission to develop land and could require the manager to grant planning permission which would result in a material contravention of a development plan. Regrettably, such powers provided the opportunity for corrupt influence to be brought to bear over such matters as applications for land rezoning in the suburbs. Executive responsibilities include the discharge of all functions not reserved to the elected members, including decisions relating to planning applications. In these matters, the manager is assisted by professional staff who act in an advisory capacity. Thus, there has been a sharply hierarchical administrative structure whereby the City Manager has wide responsibility. The structure has also created a distinction between development control and planning policy functions.

The basis of contemporary Irish urban planning lies in land-use zoning and development control. The 1963 Planning Act confirmed local authorities as the appropriate planning bodies and imposed a duty on each authority to adopt a 
development plan for its area. Private- and public-sector developers are obliged to obtain planning permission for any proposed development or change of building use, the local authority planning department ensuring that proposals conform with the development plan. In addition to ensuring compliance with the designated land-use zoning for the area, planners control the scale of the development scheme by regulating plot density and building height, and also examine all aspects of the external architectural character of the scheme.

The original emphasis of the Act was towards the active involvement of local authorities in development, power being given to them to develop or secure land for development, which theoretically permitted them to become involved in development and dealing in land. However, the absence of financial facilities to undertake such activities, which ran the risk of impinging on private-sector profitability, ensured that such powers could not be operated on a large scale. Many of the more obvious deficiencies of the current planning system derive from its structural position and the fact that its role is essentially permissory. The fact that planning departments lack spending powers severely hampers what can be achieved, as planners have to rely on the private sector and the co-ordination of other local authority spending departments for the execution of plans. This clearly places planning in a position of dependency in relation to private-sector property development and investment interests, requiring development plans to be drawn up in a manner which complements market processes (see MacLaran, 1993, ch. 5).

The position of urban planning in Dublin in the late 1980s reflected the relationship between central and local government, the structural distinction between planning policy and development control functions, and the hierarchical and bureaucratic operations of local government departments encouraged by such structuring. For instance, the bureaucratic role to which planning had been relegated within the local authority was characterised in the following way by a senior planner in the Corporation:

"I'm an official in a large organisation. Everything I do is laid out by procedure, legislation, traditional practice, guidelines...We are very hierarchical here. It's very 
authoritative which, in many ways, is a rigid straight jacket. The reality is that we operate in tight confines...."(Senior Planner, Dublin Corporation, 1996)

This positioning accounts for the range of central government interventions into matters of inner city renewal which date from 1986.

\section{Towards Entrepreneurialism}

From the mid 1980s, central government policies increasingly dominated urban-related interventions as Dublin's governance took on the institutional dimensions of the 'entrepreneurial city' (Hall and Hubbard 1998). The most important of these interventions were those which targeted the problems associated with inner-city decline. However, in the process of devising policies which were to have a major impact on the thrust of redevelopment in the city until the end of the century, little or no discussion or consultation took place between relevant central government ministries and local government departments ( $\left.\mathrm{M}^{\mathrm{c}} \mathrm{Guirk,} 2000\right)$.

The lack of central government confidence in the capacity of Dublin Corporation to tackle the scale of problems which it faced during the mid 1980s, particularly those of dereliction and building vacancy in the inner area, was revealed in the government's decision largely to override the Corporation's role through the introduction of specific urban renewal policies. These drew little upon the expertise of the Corporation, depended little upon its cooperation and permitted its effective contribution only if it were able to transform its mode of operation. An observation of a senior property investment manager (1996) with a major financial institution controlling a sizeable property portfolio reflects the widespread negative perception of the capacity of local authority planning and the private sector endorsement of centralised intervention:

"Dublin is a good case-study of the rapid evolution of urban policy. There was a situation where planning policy was very negative and restrictive right up to the mid 1980s. There was rigid zoning...None of it worked. It was counter-productive. Developers simply found their way around it. All it succeeded in doing was raising property values in the sought-after areas...For the first time, there was serious acknowledgement that property capital is induced by capital allowances being made available to occupiers. This was a leap forward for public policy makers...It says a 
lot that the Department of the Environment...colluded with the Department of Finance, not Planning".

The central government renewal initiatives were to have a profound impact on the inner city by sparking a development boom in the office and residential sectors. They also contributed to a significant transformation in the operational climate of the Corporation.

The centralised renewal initiatives can be categorized in to four stages. First, an Urban Renewal Act (1986) empowered the Minister of the Environment to designate certain urban areas as being in need of renewal (Figure 1). Here, financial incentives were to be made available to promote property-led regeneration. The Finance Act (1987) provided for special tax reliefs to apply in such Designated Areas to encourage new construction, including capital allowances for commercial development, subsidies to occupiers by means of rates remissions and additional rent allowances for commercial activities (MacLaran, 1993; Williams and MacLaran, 1996). Special income tax allowances were also provided for residential owner occupiers. In designating such areas, the effective input of local government planners had been minimal and this marginalisation of Corporation planners from the processes of planning for inner-area renewal engendered deep feelings of alienation. This was forcefully expressed by a senior planner in the Corporation with respect to the Designated Areas:

"I want to know who is drawing up those boundaries, who is doing it, what is the functional reason for it. I'm not really involved at all. Central government's accountability is not really clear. Without being conspiratorial about it, there is this golden circle with entrepreneurs, the Department of the Environment, the Department of Finance and the special structures set up in a comfortable relationship with the private sector. The local authority is coming from a low base. We don't have the resources. We just get the crumbs... Our ideas are not on the table in discussion of these things" (Senior Planner, Dublin Corporation, 1996).

Though communication improved somewhat when later rounds of Designated Areas were introduced, local government planning involvement remained highly contingent.

\section{TAKE IN FIGURE 1 AROUND HERE}

Second, a special purpose authority was created which was charged with the renewal of the disused Custom House Docks. The Custom House Docks Development Authority 
was given full planning powers and charged with overseeing and promoting the redevelopment of unused dockland close to the city centre amounting to 11 ha., later extended to 20 ha.. An integrated development project was envisaged which would include a wide range of business, residential and recreational functions. Subsequently, plans for an International Financial Services Centre (IFSC) were added, where even more generous incentives were provided and where additional company taxation incentives were made available to encourage off-shore office-related financial operations. The process of redevelopment was thrown open to prospective developers by means of a competition to produce development schemes which would conform to the outline plans of the Authority.

Third, the Temple Bar Area Renewal and Development Act, 1991, and the provisions of the Finance Act of the same year, established two companies to oversee the rehabilitation of the Temple Bar district, an area exceeding 80 ha. situated in the citycentre separating the two main elements of the retailing core. The district had suffered from blight and the abandonment of building maintenance resulting from long-standing plans to redevelop a sizeable site as a bus station. The key to regeneration was the creation of a cultural and tourist quarter by protecting and enhancing the types of function which were already appearing in the area. Although the Corporation retained its formal planning control functions in Temple Bar, the new initiative paid little heed to the Corporation planners' existing detailed 'action plan' for the area (Dublin Corporation, 1990). Unlike elsewhere in the Designated Areas where tax incentives were available for all property-related developments, incentives in Temple Bar were more restrictive, available to private-sector developers only for buildings which accommodated functions approved by Temple Bar Renewal Ltd., the company charged with the task of creating the required functional mix. A second company, Temple Bar Properties Ltd., acted as a development company for the area. At pre-incentive prices, it took over all the available publicly owned properties in the district, primarily the property portfolio of Coras Iompair Eireann (CIE), the transport authority which had been acquiring premises for redevelopment as the bus station. Thereafter it embarked swiftly on a programme of refurbishment and infill construction projects. Thus, despite retaining development 
controls, the role of the Corporation planners was effectively marginalised by the financial position of Temple Bar Properties and by its property ownership (Montgomery, 1995). This division of competence generated significant difficulties between the parties when radical development initiatives were proposed by the renewal authorities.

Fourth, in the mid 1990s central government's creation of two designated Enterprise Zones further eroded local government planners' role. The zones were situated adjacent to the docklands where fiscal incentives were provided to promote industrial operations. However, it was the national Industrial Development Authority, rather than the Corporation, which was charged with securing and approving appropriate companies. The Authority adopted a broad interpretation of the functions deemed appropriate for support and a wide range of activities were attracted, including software companies, teleservices and research, most of which are office-based. By the end of 1999, over 78,000 sq. m. of office space had been developed on these two sites.

These four strategies comprised those same strategies that had marked the emergence of an entrepreneurial culture underlying urban regeneration in the UK and Europe (Judd and Parkinson, 1990; Deakin and Edwards, 1993). Property-led regeneration initiatives (Healey et al, 1995; Turok, 1992), flagship developments (Smyth,1994; Crilley, 1993) and regeneration based on the exploitation of cultural capital (Boyle and Hughes, 1994) were common features of the 'entrepreneurial turn' in UK urban governance. In Dublin however, entrepreneurial efforts were largely focused around a narrowly conceived physical regeneration (with some exploitation of cultural capital in Temple Bar), driven by central government fiscal incentives. While the private sector developers were willing recipients of these fiscal incentives, more active forms of partnership were poorly developed compared to the active role in evidence in the UK where partnerships extended beyond physical regeneration into broader economic development, education and training provision, and the provision of entrepreneurial leadership (Harding, 1991; Fainstein, 1994; Peck, 1995).

Though some concern for social outcomes was evident in the renewal of Temple Bar, a more broadly conceived regeneration—beyond physical renewal-fell outside the remit 
of Dublin's entrepreneurial governance until the late 1990s. Attention was focussed on a piecemeal, if widespread, patchwork of physical redevelopment schemes unconnected to any broader vision of urban policy (Bartley et al, 2000). While this approach had been subject to damaging assessments in the UK (Wilks-Heeg, 1996; Haughton and While, 1999), it continued to be practiced in Dublin until the late 1990s. The centrally-driven nature of Dublin's entrepreneurial governance may account for this approach outlasting its demise in the UK. While local government in Dublin has been in a structurally weak position, until very recently it had also maintained a highly managerial rather than entrepreneurial approach. Thus, it had been both poorly equipped and poorly disposed towards engaging actively in forging entrepreneurial partnership with the private sector in pursuit of more widely-conceived regeneration strategies. By contrast, in the early 1990s, the 'new localism' of central government funding schemes in the UK reestablished the role of local government within entrepreneurial urban physical, social and economic regeneration, albeit in a scripted and circumscribed manner, fashioned around notions of local innovation and competitiveness (Stewart, 1994).

While a range of entrepreneurial central government initiatives were shaping inner Dublin's redevelopment, increasing pressure was put on the local authority from central government and from the private sector to respond pro-actively to the development opportunities being realised through central government incentives. The response emerged not from the Planning Department but from the Corporation's Development Department. Here, an Inner City Development Team (ICDT) was formed in the late 1980s to promote the Designated Areas as suitable locations for profitable development and to provide a facilitative channel through which prospective inner-city developers could be directed. The ICDT acted as a catalyst for the renewal programmes by using the sale of inner-city Corporation-owned sites, many of which were earmarked for social housing development schemes for which exchequer funding was unlikely to be forthcoming in the foreseeable future, to broker innovative development deals in which the aims of the renewal process were advanced. The team nurtured a co-operative, negotiative relationship with private sector interests, operating as both mediator and catalyst ( $\mathrm{M}^{\mathrm{c}} \mathrm{G}$ irk, 2000). With a negotiated development brief in place, Corporation sites were released to selected developers. Escape 
clauses were built into the agreements to entice developers to take on projects which were considered risky at that time. However, the team's operations were expressly prodevelopment and were disconnected from any wider social context which might have emerged from co-ordination of their operations with broader planning policies. One member of the ICDT summarised the team's approach, highlighting differences between its operation and the local authority's usual mode of operation:

"The team we put together was headhunted. We needed people with entrepreneurial flair. You had to emancipate yourself from the bureaucracy and adopt a pro-active attitude....We have tried to put a stamp on the way we deal with development - a way that is different to the bureaucratic way" (Member of the Inner-City Development Team, 1996).

In this manner, 78 projects were developed on Corporation-owned land by the end of 1996 (Dublin Corporation, 1997).

Increasingly, planners were obliged to adopt a spectator role as important elements of planning control and the promotion of development were determined by or became vested in authorities lying outside the remit of Dublin Corporation. Where Corporation planners did remain involved, they became increasingly co-opted by a pervasive prodevelopment managerial structure:

"The current entrepreneurial spirit must be seen in context. The recession brought masses of dereliction, inner decay and a burgeoning periphery. There was no indication that it would reverse. It needed intervention. The market just won't take something on if it's unprofitable. The image along the quays was very poor. So was the core inner city. That led to the 1986 tax incentives. They were a way to get a spark going...In the Planning Department, it was not that the rules were bent but that they were interpreted favourably rather than unfavourably" (Senior Manager, Development Department, 1996)

Thus, negotiative, enterpreneurial styles of urban governance were emerging through the collaborations of the private sector and some sectors of local government, driven by central government renewal initiatives. The ICDT was operating in a highly entrepreneurial fashion and had positioned itself as a key local government actor able to influence policy outcomes (see Charlesworth and Cochrane, 1994; Mayer, 1994). Local 
authority planners, however, were failing to mobilise their potential inputs into the emerging institutional context of inner Dublin's urban governance and remained largely excluded from the networks of negotiation which increasingly characterised that governance.

\section{Impacts on Renewal}

As a local government function which is essentially permissory or passive, relying on and reacting to private-sector initiatives, local government planning occupies at the best of times a position of weakness relative to the development interest which it attempts to control. During periods of development quiescence, as in the mid-1980s when few schemes were being initiated in Dublin, planners came under intense political pressure to grant planning permission for almost any proposed development scheme ( $\mathrm{M}^{\mathrm{c}} \mathrm{Guirk}$, 1992). In contrast, during property booms, planners become over-burdened by the sheer volume of planning applications. Thus, over recent years, Corporation planners have had to cope with the ramifications of a construction boom which have had a profound impact on the physical and social environment of inner Dublin (MacLaran, 1996a, 1996b, 1999, MacLaran et al, 1999, Williams and MacLaran, 1996) but which resulted from a renewal policy that operated in the absence of any planned strategic framework and which planners had possessed little opportunity to influence.

The timing of the introduction of the Designated Area incentives was fortuitous and had an immediate impact on office development, having taken place just as the offices sector was about to enter a phase of intense development activity. In 1989, the vacancy rate in Dublin's stock of modern (post-1960) office space was below 4 per cent. In response to rising economic growth, the completion of new office space leapt from its mid-decade annual norm of less than 25,000 sq. m. to over 80,000 sq. m. in 1990, a further 120,000 sq. m. reaching completion during the following year. Within two years, the stock of modern (post 1960) office space in Dublin had expanded by over 18 per cent. More than a quarter of this new development, amounting to 60,000 sq. m., was located in Designated Areas, including the IFSC. However, by the early 1990s, completions outpaced the take-up for new space. Vacancy rates soared, reaching 11 per cent in late 1991 
with 60 per cent of vacant stock located in new buildings. Moreover, office establishments proved reluctant initially to contemplate the untried secondary locations where designation occurred. As a result, in the Designated Areas outside the IFSC, some 45 per cent of the newly developed space lay vacant. Inner-city sites in such locations therefore increasingly became considered for alternative functions, primarily residential development (MacLaran 1996b).

During the 1980s, a limited amount of private-sector residential development had been attracted to inner Dublin locations as a result of incentives provided by Section 23 of the Finance Act, 1981, (renewed in the 1988 Act under Section 27). These permitted landlords to set against taxable income the costs (net of the land element) of acquiring properties for rent. The immediate effect was to engender a surge of apartment construction, initially in Dublin's inner suburbs. However, by the late 1980s, a few tentative schemes were developed in clearly tertiary inner-city locations where virtually no private-sector residential development had taken place during the twentieth century. In 1991, the availability of such Section 23/27 reliefs became restricted to the Designated Areas, contributing to the geographical refocusing of developments. Proximity to the central area became a strong marketing feature and the schemes sold well, not only to landlords but, more surprisingly, to young middle-class owner-occupiers. By early 1997, some 6,000 dwellings had been developed in the Designated Areas, with a further 2,700 units even being developed on inner-city sites which lacked such incentives (MacLaran, 1996b; MacLaran et al, 1994; MacLaran et al, 1995; MacLaran and Floyd, 1996; Williams and MacLaran, 1996).

However, despite the volume of planning applications for development which were forthcoming, Corporation planners proved unable to avail of opportunities to harness the growth impetus of highly successful property-led regeneration which might have enabled them to widen social renewal in a manner which was more closely linked to a strategic planning framework (KPMG, 1996). This resulted from their remaining locked outside the policy networks responsible for determining the path of inner Dublin's regeneration 
during a major period of renewal. This situation was well summarised by a senior property investment manager controlling a significant Irish portfolio:

"The Designated Areas were a typical civil-servant response really; a little simple minded. It gives their political masters what they want. If there was a genuine partnership between the planners and the Department of the Environment there could have been a more sophisticated response. There is very little co-ordination on public policy between local government, central government and state quangos which operate almost without reference to anyone else..... There is an enormous lack of co-ordination which has given rise to a major loss of opportunity" (Bruder, 1996).

The creation of special purpose authorities has often been a key element in the undermining of planning's broader functions beyond that of development control (Newman and Thornley, 1996, Malone, 1996). This is no less the case in Dublin where the newly created bodies drew little upon the expertise of the Corporation and precluded its effective contribution to policy development or programme implementation. A senior Corporation planner candidly summarised this as follows:

"The ad hoc bodies are a threat to us. They don't want our type around. even within our own organisation there is an underlying feeling that any two-bit consultant planner is the way to get things done. I wasn't consulted about the new Docklands proposal. Our (City) Manager was on it. But he's not telling me..." (Senior Planner, Dublin Corporation, 1996)

The same planner illustrated the recognition of their growing marginalisation suggesting that there was a pervasive feeling among local authority planners that others were "stealing their clothes" (Senior Planner, Dublin Corporation, 1999).

\section{Urban Planning: a search for relevance}

In the light of the recognition of substantive marginalisation, local authority planners have been faced with a search for relevance which has coincided with a re-evaluation of the merits of centralised property-led regeneration. In the UK, growing recognition of the failures of property-led regeneration to inspire lasting urban economic revival and sustainable social regeneration (Turok, 1992) has led, inter alia, to the adoption of more holistic approaches to achieving urban renewal (Haughton and While, 1999). A holistic 
conception of planning for urban renewal has emerged from philosophical shifts within planning theory. Increasingly planning activity is conceptualised not as the functionalist notion of 'the regulation of landuse' but as the holistic notion of managing the landuse demands of society's collective activities in space (Healey, 1997). By definition, this view of planning reaches beyond planning for physical renewal to incorporate planning for the range of economic, social and environmental factors which impinge upon collective activities and their spatial requirements.

The emergence of a holistic approach to planning is also connected to the political economy of contemporary cities in which 'quality of life' has become a factor of competitive advantage in the on-going struggle to attract mobile capital (Healey, 1997; Crofts, 1998). Likewise it is connected to 'third way' political ideologies which aim to redress the social and environmental costs of the neo-liberal ideologies which legitimated such policy directions as property-led redevelopment (Haughton and While, 1999). An emphasis on holistic planning stresses that physical development must be accompanied by social and community development and underpinned by appropriate economic development. Planning to achieve the integration of such multi-faceted development requires cross-sectoral collaboration to draw on public, private and community sector capacities. Thus the notion of holistic planning dovetails with the notion of partnership which is closely identified with entrepreneurial forms of urban regeneration planning. Likewise it dovetails with the assertion of community demands to address the democratic deficit of early examples of entrepreneurial planning renowned for poor accountability (Brownill, 1993; Leitner and Garner 1993; Wilks-Heeg,1996). Holistic planning for urban renewal thus comes to be less about generating a master-plan or set of procedures to regulate physical outcomes and more about developing a process through which sustainable multi-faceted renewal can be achieved collaboratively (see Sandercock, 1998). This processual definition has been institutionalised within UK central government schemes to fund renewal. For example, the Single Regeneration Budget is predicated on developing partnerships between local government, the private sector, and the community sector to develop projects which aim to incorporate sustainable economic 
and social agendas as well as physical regeneration into policies in a more robust fashion (Fordham et al, 1999).

Mirroring events in the path of UK urban policy (Shaw and Robinson, 1998), the insights gained from harsh assessments of property-driven urban renewal policies (e.g. KPMG, 1996; McCarty, 1998) appear also to have been taken into account in Ireland. The redevelopment of Temple Bar and the Custom House Docks has been subjected to significant criticism for their failure to achieve wider social objectives or bring about broadly-based, diverse, self-sustaining solutions to urban problems (McCarty, 1998; KPMG, 1996). The redevelopment at Custom House Docks, in particular, has been criticised for marginalising the local population from its benefits, generating an enclave of high-cost housing and an office complex which remains isolated from its surroundings (Malone, 1996; Bartley et al., 2000). Despite such critiques, the central government strategy of using special purpose authorities has been maintained as a key tenet of urban policy with the creation of the Dublin Docklands Development Authority (DDDA) in 1997. The DDDA subsumed the former Custom House Docks Development Authority (CHDDA) and is charged with securing the sustainable social and economic regeneration of 526 hectares (1,300 acres) of Dublin's docklands, an area which has suffered from the physical and socio-economic decline shared by many deindustrialised ports (Drudy, 1999). However, the £1.6b Master Plan of the DDDA explicitly suggests a desire to redefine urban renewal (DDDA, 1997a, 19), expanding its definition from mere physical renewal to embrace social, economic and environmental dimensions, to be pursued in a more democratic and inclusive manner.

The Plan incorporates a strategically integrated and holistic approach to planning, pursuing physical renewal in concert with sustainable social and economic regeneration of the area, to be pursued through attracting economic investment, job creation, education and labour training programmes, the provision of social housing, the regeneration of local communities and their social integration with new residents. This is an approach which incorporates the traditional concerns of urban planning, land-use and infrastructure planning, and urban design, and uses them to drive towards the broad physical, social and 
economic objectives. The DDDA's primary role, then, is to serve as co-ordinator of a network of cross-sectoral and inter-agency responses to urban regeneration, ensuring that resources are combined and that the multi-faceted policies and actions of all the relevant agencies lead to the achievement of the goals set down in the Master Plan (DDDA, 1997b). This role as a flexible and multi-functional 'enabling authority' (Rydin, 1998) has not previously been successfully applied in the management of inner Dublin's regeneration.

Input from Dublin Corporation into the operations of the DDDA is inscribed in the legislation. The Master plan of the DDDA and the Corporation's City Development Plan are required to be consistent with each other, thus allowing the Corporation to maintain its development control function as the area's planning consent authority under most circumstances. However, the DDDA is empowered to develop special detailed planning schemes for areas thought to be in need of particular redevelopment assistance which will be exempted from the Local Government (Planning and Development) Act, 1963. Following limited consultation with the DDDA in drafting the Master Plan, the scope for further local authority strategic planning input into the implementation of the plan is restricted. The Corporation Planning Department will operate as a regulator but the opportunities to exploit resources, such as its city-wide overview, are limited, as elsewhere, by the continued entrenchment of a centre-local hierarchy (see Stewart, 1994).

Thus, Dublin's institutional and development contexts have witnessed significant shifts in both the approach to and the substantive content of urban planning and its institutional location. In the contemporary landscape of inner Dublin's governance and planning, a holistic approach to urban renewal has emerged outside local authority structures. Moreover, this approach could be said to have been buoyed by a perceptible shift in the political allegiances of the Dublin electorate which suggested support for a more considered and holistic approach to planning redevelopment. Politics in the Republic of Ireland, at central and local government levels, are dominated by a range of conservative parties (see MacLaran, 1993, 67-78). However, the 1991 local elections in Dublin witnessed the breaking of the conservative Fianna Fail party's control over Dublin 
County Council (the former administrative authority for most of the outer suburbs and rural fringe), attributed in major part to the role which its councillors had played in the rezoning of green-belt areas. The major beneficiary was the Labour Party, but the election of a significant core of Green Party councillors signalled an important change in the mood of the Dublin electorate. In the central County Borough, the election was followed by the informal establishment of a 'rainbow coalition' forged around a Civic Charter comprising a fifteen-point programme setting out a conservation-minded agenda to be followed during the five year term of office. So by the late 1990s, the task of redefining planning operations in order to enhance their relevance and effectiveness, has become a matter of central concern within local government.

\section{Integrated Area Plans, the Dublin City Development Plan, and the realignment of local government}

This section is concerned with the evolution of a changed approach to planning within the local authority, which has been underpinned by a broad realignment of local government functioning more generally. The deepening marginalisation of urban planning in Dublin from the mid 1980s was forcing a revaluation of its activities and the search for a role which departed from its historically bureaucratic functions of zoning and development control but differed from the pro-active entrepreneurialism being promoted by the special purpose authorities and by the Corporation's own Development Department. Certainly if local authority planning were to emerge from its position of marginalisation, significant reconfiguration would be necessary in institutional structures, management structures, and in the conceptualisation of the appropriate approach to urban planning activity. Such reconfiguration would need to accommodate a more holistic approach to urban planning, a mechanism for levering cross-sectoral funding and other resources necessary for the implementation of planning strategies and adopt an institutional and management structure which could accommodate a broader interpretation of planning's role (see Bassett, 1996). Such approaches to planning had been emerging within the activities of the special purpose authorities, such as the DDDA, which suggested a role for urban planning concerned less with matters of land-use control and regulation, and more with the development and implementation of broad and holistic development strategies. The 
function of the planning role here is to develop strategies and then act as an 'enabling authority', flexibly facilitating and co-ordinating the strategies' cross-sectoral implementation and acting as a catalyst to mobilise whatever synergies might arise from such collaboration. To date, local authority planning authorities had failed to develop this role.

The evolution of a new approach within the local authority mirrors the currents of change evident within central government urban management and regeneration initiatives, within the approach of private sector-dominated special purpose authorities, and within increasingly insistent demands from community and voluntary sector groups for localised regeneration strategies. In contrast to the well-financed area-based renewal initiatives emanating from central government, there existed throughout this period constant pressure on Dublin Corporation from community-based initiatives aimed at engendering a process of regeneration which would be relevant to the requirements of inner-city neighborhoods. These initiatives included the drawing up of local plans such as that for the Liberties, devised by the South Inner City Community Development Association. While the lack of necessary funding from either Dublin Corporation or the central government relegated the role of such documents to mere statements of hope, it was abundantly clear that such communities had strong ideas about the future for their localities and were unwilling to accept authoritarian planning approaches (see Stoker, 1991). Such insights were not lost on Corporation planners and appear to have influenced the development of an alternative approach to local government planning grounded in micro-area planning.

A forerunner of micro-area planning had already emerged in the Corporation's Action Plan for Temple Bar (1990). The use of the local area plan had emerged after the Corporation's rejection of CIE's plan to develop a transportation Centre. The Plan took cognisance of the thinking which underlay the submission by Temple Bar Development Council, a coalition of traders and local residents, on the Development Plan. It proposed a strategy of environmental upgrading, tax incentives for refurbishment, the encouragement of mixed uses and the development of the area for cultural tourism (McCarty, 1998). 
Although the Plan was largely obviated by the special provisions established by the central government to oversee the renewal of that area, the validity of micro-area planning, and the legitimacy which community-based planning imparted, provided a refuge in which planners could again exercise their penchant for "proper planning". This was to be demonstrated most clearly in the holistic Historic Area Rejuvenation Project (HARP) — an initiative of Dublin Corporation aimed to run from 1995-1999 with a budget of $£ 12 \mathrm{~m}$ collaboratively funded by the European Union's Operational Programme for Local Urban and Rural Development. The HARP plan took shape simultaneously with the drafting of the Master Plan for Docklands (1997) and reflects a similar holistic and integrated planning approach. The plan was developed in close consultation with local business interests, residential and community groups and voluntary and statutory agencies in the area (including employment training agencies). Major priorities identified during the consultation process included the need for physical renewal and strategies to attract and facilitate local economic activity with the specific intent of providing local employment. In addition, provision was made for the improvement of social amenities, local educational access, training and youth development and to enhance opportunities in the local social economy. HARP is "influenced by principles of sustainability, mixed used and equity which integrate economic, environmental and social strategies, crosssectoral involvement and participation" (Gleeson, 1999, 52).

This local area approach was subsequently embodied in the Corporation's Integrated Area Plans (IAPs), a holistic and integrative approach to urban planning which mirrored the approach of the special purpose authorities, particularly that of the DDDA. IAPs are localised planning mechanisms which aim to embrace the complexity of contemporary urban systems though developing a holistic approach towards the achievement of social, economic and environmental goals while encouraging the necessary inter-sectoral coordination to achieve such aims (See TABLE 1). Whereas traditional planning approaches have been described by the Deputy City Planning Officer as tending to simplify the city through land-use policies which emphasise segregation, the framework of the IAP "facilitates the structuring and management of local complexity... thus encouraging a rich mix of land uses ..." (Gleeson, 1999, 52). 
Broadly, the use of IAPs as a planning mechanism suggests a reaction to the marginalisation of local authority planning from the course of Dublin's regeneration and a search for a new legitimacy and relevance. Their use is indicative of a shifting philosophy within the Corporation on the appropriate function of planning activity and the adoption of an entrepreneurial planning philosophy which asserts planning's potential co-ordinating functions and stresses its interactive role with respect to private sector interests, public interventions and local communities (Stoker and Young, 1993; Hall and Hubbard, 1998). The IAP approach is aligned with a style of 'entrepreneurial planning' (Hall and Hubbard, 1998) aimed at minimising supply-side restrictions, providing education and training and enterprise support, while providing indirect state subsidies in the form of tax incentives (see Painter, 1998). This is an approach born of a governing context in which large-scale state direct subsidy and strict development regulation are unlikely to return but also in which the failures of market-driven redevelopment policies (such as property-led regeneration schemes) are recognised. It was also encouraged by requirements that social partnership and social exclusion be addressed within any schemes which would attract EU funds.

For the community and voluntary sector, the IAP approach to planning, exemplified in HARP, offers an institutional location in which networks between organisations can be improved and networks with business interests and public sector agencies can be more easily developed (see Stoker, 1991). For business interests, the IAPs provide a co-ordinating framework within which development opportunities can be facilitated and integrated with the provision of supporting infrastructure. For local authority planners, the IAPs provide a potential antidote to marginalisation, creating for them a central co-ordinating and locallybased strategic role in development and regeneration. In addition, by virtue of their crosssectoral nature, IAPs offer local-authority planners a means of levering funding to implement renewal strategies through partnerships with the private sector, through co-ordinating and targeting existing public spending (from other government agencies) in alignment with the priorities of the IAP and by identifying and drawing down alternative funding sources (e.g. EU funding programmes). Thus, the IAPs represent the key co-ordinating framework through 
which local government planning can mobilise its resources to co-ordinate local government service provision and spending capabilities while marshalling private investment and local community efforts towards achieving desired local development outcomes.

Since HARP, the use of the IAP approach has become formalised by being adopted by central government as the key element in its most recent Urban Renewal Scheme (DoELG, 1998). A major assessment of the impact of central government incentive-driven redevelopment suggested that incentives in the future be applied in a more focused fashion and be contextualised within more integrated schemes for physical, economic and social renewal (KPMG, 1996). The Government's response was to develop an urban renewal scheme in which incentives can only be made available in specified locations which comprise part of broader areas in need of renewal and for which an IAP has been developed by the local authority to target areas' holistic renewal. This strengthens the position of local authority planners, whose input had been largely absent from previous renewal schemes ( $\mathrm{M}^{\mathrm{c}} \mathrm{Guirk}$, 2000). The approach formalises a broadly conceived role for urban planning while institutionalising a cross-sectoral, partnership-oriented approach to implementing the holistic planning strategies articulated in the IAP. However, the link between IAPs and the central government Urban Renewal Scheme represents a channel through which central authority and policy directions can be re-asserted. A similar central-local relationship characterises the UK's Single Regeneration Budget (Wilks-Heeg, 1996). The required dimensions and components to be contained in IAPs are specified in the scheme guidelines and include the necessity for widespread participation and involvement together with partnership in the preparation, implementation and monitoring of the IAPs. Within this approach to urban renewal, local authorities act as entrepreneurial 'enabling authorities', drawing on a holistic notion of planning and using IAPs at the mechanism to draw down incentive funding for redevelopment, emphasising their role as facilitative co-ordinators of the cross-sectoral implementation of planning strategies. The conceptualisation of the role of planning envisaged here is integrative, proactive and flexible rather than sectoral, reactive and regulatory (see Cochrane, 1991). 
Since the publication of the Government's Urban Renewal Scheme Guidelines (1998), Dublin Corporation has released the Dublin City Development Plan (1999), aimed to be a "more stream-lined strategic plan, capable of responding to the complex development needs of the city" (Dublin Corporation, 1999, 9). The emphasis on planning's catalytic role and its integrative functions is pronounced and this represents a major repositioning. IAPs are a core element of the Plan, intended to provide a locally flexible planning framework capable of coping with the complexity and variability underpinning urban development conditions. This approach is described by Deputy City Planning Officer as representing "a major departure from the long-established approach of the City Development Plan" (Gleeson, 1999, 52). The underlying philosophy of the IAP approach infuses the plan more broadly to reflect a holistic planning philosophy in which the traditional emphasis on environmental aspects is expanded to be integrated with an agenda of achieving social and economic objectives.

This current City Development Plan (1999) was formulated during a period of considerable shift in the management philosophy, techniques and hierarchical organisation of Dublin Corporation towards an explicitly entrepreneurial mode of operation. In the mid 1990s, government policy has addressed the reform of local administration with a view to enhancing democracy and participation, improving service delivery and the efficiency of local government operations, together with addressing the problem of local authorities' resource base. During the 1990s, local government in Ireland has been in a state of flux. The reorganisation of administrative authorities in the capital together with changes in managerial personnel in the Corporation and suburban authorities, have facilitated rapid change in the administrative organisation of the city. The release in 1996 of central government's Strategic Management Initiative (Dept of the Taoiseach, 1996) hinted at the planned departure from traditional bureaucratic modes of governance in favour of more flexible new public management techniques. The publication in the same year of the Better Local Government Report (DoELG, 1996) signalled central government's desire to pursue this agenda locally through forging a holistically- rather than functionally-divided approach to local governance (Bartley et al, 2000). Furthermore, it has been the intention of the central government to limit further 
the role of the managers in favour of the democratically elected councillors (DoELG, 1996).

It was in this climate that a Corporate Planning Unit was formed with a brief to analyse and facilitate changes to the Corporation's organisational structure and to instill a new operational culture into the local authority's ethos, to be implemented during 1999 (Dublin Corporation, 1998). It is intended that the reorganisation of Corporation departments will reflect a new devolution of political decision making. The Corporation has been restructured from its organisation on a functional basis to one based on five geographically-administered Area Departments with responsibility for management and delivery of a range of services relating to planning and urban design, environment and engineering, and housing and community services. Staff will work in multidisciplinary project teams across a further five integrated City-wide Departments which will cover services which are considered more appropriate to a broader geographical base for delivery, including economic development and planning, transportation and traffic, housing, social and community affairs, arts and culture, together with certain broader aspects of environment and engineering. Included in the Planning and Economic Development Department are the recently formed Economic Development Unit aimed at attracting and facilitating inward investment and a Development Advisory Team which will assist property owners and developers in progressing development proposals for targeted sites within IAPs. Finally, six central departments, addressing finance, staffing, law and corporate affairs, together with the city manager's department, provide support to Area and City-wide Departments. Finally, addressing the central government desire to redress the balance of power between managers and democratically elected councillors (DoELG, 1996), six Strategic Policy Committees involving councillors have been established within Dublin Corporation to address sectoral issues which affect local communities. In addition Area Committees made up of councillors and local appointees have been established. The implementation and operationalisation of these structural, and associated cultural, realignments will take some time, being in the words of one local government official 'a mammoth task'. 
Dublin Corporation has gone about reinventing itself as a flexible, outcomes-oriented and entrepreneurial entity. Management is anxious that the Corporation should be represented as capable of working flexibly with private and community-sector organisations to produce new modes of governance. The Corporation's new managerial ethos is concerned both with providing service efficiency and with city boosterism, promoting and selling the city in order to attract investment in a highly competitive environment. One senior planner (1999) referred to the Corporation as 'Dublin Inc.' which was 'like a firm running the city according to a corporate vision of build, build, build'. In this process, the marginalisation of local government planning from urban renewal is being explicitly addressed. The IAP approach to planning as enabling, facilitating and co-ordinating wide-ranging economic and social development sits more comfortably with this corporate vision and management philosophy than more traditional forms of planning practice which had until recently characterised Corporation planning practice.

While the IAP approach offers enhanced local strategic involvement to local authority planners and provides enhanced means of plan implementation through partnerships, this involvement is always tempered by the need to forge working partnerships and to remain aligned with central government directives. The efficacy of entrepreneurialism, competitiveness and managerialism as offering potential empowerment to local authority planners has been argued elsewhere to be illusory (Stewart, 1994; Imrie and Thomas, 1995; Lovering 1995: Wilks-Heeg, 1996). Local priorities may be marginalised by the privileging of economic efficiency over social concerns, making localities vulnerable to powerful discourses of entrepreneurialism, globalisation and place competitiveness (Leitner and Garner, 1993; Tickell and Peck, 1996; $\mathrm{M}^{\mathrm{c}}$ Guirk et al, 1998). In the Dublin context, the same senior planner suggested that the new corporate ethos left little role for local authority planners to function as 'independent advisors' on development options. Likewise, he suggested that the potential of the entrepreneurial approach to enable planners to implement the social dimensions of planning schemes is compromised by a pro-development local authority corporate vision at the managerial level. 


\section{Conclusion}

A review of the recent transformation of planning in Dublin focuses on a number of key issues. It is apparent that deepening entrepreneurialism in urban governance has necessitated the reshaping of urban planning operations. Despite the growing facilitative orientation with respect to development, the changes have led to a welcome diminution of planners' traditional fixation with physical development control and a rediscovery of planning's service function, emphasising a concern for forging connections with the community and engagement with issues of resourcing and service provision.

However, as Dublin's experience of micro-area planning remains limited, it is imperative to retain a critical stance towards the manner in which the process operates and towards its results. First, in spite of an almost unprecedented range and depth of consultations which took place between planners and local communities in relation to the HARP redevelopment project, the major consequence has again been one of large-scale property development and the influx of a middle-class residential population. An inclusive approach to planning urban renewal is no guarantee of socially inclusive outcomes. Thus the IAP approach offers no grounds for complacency regarding the pursuit of local community renewal through non-planning means. Secondly, although one might welcome the adoption of consultative and negotiative strategies as more central elements in the operation of Irish urban planning, with the possibility that these become formalised in a system of local area planning committees, the deepening entrepreneurial orientation of urban governance in the city has simultaneously tended to refocus planning functions towards short-term facilitative operations, 'quick response stuff', to quote one Senior Planner, 'which gives very little attention to the overall picture'. This creates local vulnerability to trading-down holistic development aspirations in the name of placecompetitiveness. Indeed, an entrepreneurial focus which tends to emphasise localised and short-term issues is increasingly at variance with recent debates regarding the need to produce sustainable community developments which can embed investment which is otherwise prone towards mobility (Raco, 1998). 
Wariness of growing localism in planning is particularly important in a metropolis in which administrative and planning functions are divided between several local authorities, increasingly vying with one another to attract lucrative commercial rates (property tax) generating retailing and office functions. While the provision of infrastructures to service such commercial development lies outside the remit of the local authorities individually, metro-wide planning has been relegated merely to the drafting of strategic Development Guidelines by private-sector consultants working to a brief provided by the non-statutory Dublin Regional Authority (Brady Shipman Martin et al, 1999) which itself has only existed since the mid 1990s. The Authority was established as a means of representing and coordinating the operations of the four local authorities in the metropolitan area and the surrounding local authorities. The authority has little real power in metropolitan coordination and no financial resources to effect the development of the necessary strategic metropolitan infrastructures. Thus, as Dublin's periphery takes on the character of a north-American 'edge city' with looming suburban gridlock (MacLaran, 1999), it is imperative to remain critical of the deepening infatuation with micro-area planning for fear that strategic planning issues become neglected as local authorities become more inwardly focused and take their collective eyes off metro-scale development. 


\section{References}

BARnEKOV, T., BOYle, R. and RICH, D. (1989) Privatism and Urban Policy in

Britain and the United States. Oxford: Oxford University Press.

BARTLEY, B., and TREADWELL SHINE, K.

(2000) Governance and the Dynamics of Urban Regeneration in Dublin. Urban Redevelopment and Social Polarisation in the City (URSPIC) Final Report on the CHDDA. Targeted Economic and Social Research (T.S.E.R.) EU Commission.

BASSETT, K. (1996) Partnerships, business elites and urban politics: new forms of governance in an English city?, Urban Studies, 33, pp 539-555.

BOYLE, M. and HUGHES, G. (1994) The politics of urban entrepreneurialism in Glasgow, Geoforum, 25, pp 453-470.

BRADY SHIPMAN MARTIN et al (1999) Strategic Planning Guidelines for the Greater Dublin Area. Dublin: Dublin Corporation.

BRINDLEY, T., RYDIN, Y. and STOKER, G. (1996) Remaking Planning: the Politics of Urban Change. London: Routledge.

BROWNILL, S. (1993) The Docklands experience: locality and community in London, in R. Imrie and H. Thomas (Eds) British Urban Policy and the Urban Development Corporations, pp 41-57. London: PCP Press.

CHARLESWORTH, J. and COCHRANE, A. (1994) Tales of the suburbs: the local politics of growth in South East England, Urban Studies, 31, pp 1723-1738.

COCHRANE, C. (1991) The changing state of local government, Public Administration, 69, pp 231-303.

CRILLEY, D. (1993) Megastructures and urban change: aesthetics, ideology and design in P. Knox (Ed) The Restless Urban Landscape. pp 127-164. Englewood Cliffs, NY.

CROFTS, D. (1998) Place management, Australian Planner, 35, pp. 49-53 
DEAKIN, N, and EDWARDS, J. (1993) The Enterprise Culture and the Inner City. London: Routledge.

DEPARTMENT OF ENVIRONMENT AND LOCAL GOVERNMENT (1996) Better Local Government: A Programme for Change. Dublin: Government Publications Office.

DEPARTMENT OF ENVIRONMENT AND LOCAL GOVERNMENT (1998) Urban Renewal Scheme, Guidelines. Dublin: Government Publications Office.

DEPARTMENT OF THE TAOISEACH (1996) Second Report to Government of the Co-ordinating Group of Secretaries: Delivering Better Government: Strategic Management Initiative: A Programme of Change for the Irish Civil Service. Dublin: Government Publications Office.

DDDA (1997a) Dublin Docklands Area Master Plan. DDDA: Custom House Quay, Dublin 1.

DDDA (1997b) Dublin Docklands Area Master Plan Report on Progress. DDDA: Custom House Quay, Dublin 1.

DRUDY, P.J. (1999) Dublin docklands: the way forward, in J. Killen and A. MacLaran (Eds) Dublin: Contemporary Trends and Issues for the Twenty-First Century, pp 35-49. Geography Society of Ireland: Special Publication 11.

DUBlin CORPORATION (1990) The Temple Bar Area Action Plan 1990. Dublin Corporation: Dublin.

DUBLIN CORPORATION (1997) Half Yearly Report on Urban Residential Renewal. Dublin Corporation: Dublin.

DUBLIN CORPORATION (1998) Modernising Dublin Corporation. Dublin: Civic Offices. 
DUBLIN CORPORATION (1999) Dublin City Development Plan. Dublin Corporation: Dublin.

EDWARDS, J. (1997) Urban policy: the victory of form over substance, Urban Studies, 32, pp 825-843.

FAINSTEIN, S. (1994) The City Builders: Property, Politics and Planning in London and New York. Oxford, Blackwell.

FORDHAM, G., HUTCHINSON, J. and FOLEY, P. (1999) Strategic approaches to local regeneration: the Single Regeneration Budget Challenge fund, Regional Studies, 33, pp $131-141$.

GLEESON, D. (1999) Changing approaches to planning in Dublin's inner city, in J. Killen and A. MacLaran (Eds) Dublin: Contemporary Trends and Issues for the Twenty-First Century, pp 49-55. Geography Society of Ireland: Special Publication 11.

GOLDSMITH, M.and KLAUSEN, K. (1997) European Integration and Local Government. Cheltenham: Elgar.

HALL, T. and HUBBARD, P. (1998) (Eds) The Entrepreneurial City: Geographiers of Politics, Regime and Representation. Chichester: Wiley.

HARDING, A. (1991) The rise of urban growth coalitions, UK-style?, Environment and Planning C: Government and Policy, 9, pp 295-317.

HAUGHTON, G. and WHILE, A. (1999) From Corporate city to citizens city? Urban leadership after local entrepreneurialism in the United Kingdom, Urban Affairs Review, 35, pp 3-23.

HEALEY, P. (1995) Discourses of integration: making frameworks for democratic urban planning in P. Healey, S. Cameron, S. Davoudi, S. Graham and A. Madani (Eds) Managing Cities; The New Urban Context, pp 251-272. Chichester: Wiley.

HEALEY, P. (1997) Collaborating Planning: Shaping Places in Fragmented Societies. London: Macmillan Press. 
HEALEY, P., CAMERON, S., DAVOUDI, S., GRAHAM, S., and MADANI (1995) (Eds) Managing Cities: The New Urban Context. Chichester: Wiley.

IMRIE, R. and THOMAS, H. (1993) (Eds) British Urban Policy and the Urban Development Corporations. London: PCP Press.

IMRIE, R. and THOMAS, H. (1995) Urban policy processes and the politics of urban regeneration, International Journal of Urban and Regional Research, 19, pp 479-494.

JUDD, D. and PARKINSON, M. 1990 (Eds) Leadership and Urban Regeneration: Cities in North America and Europe. Sage: Newbury Park, Calif.

KPMG (1996) Study on the Urban Renewal Schemes. Department of the Environment: Dublin.

LEITNER, H. and GARNER, M. (1993) The limits of local initiatives; a reassessment of urban entrepreneurialism for urban development, Urban Geography, 14, pp 57-77

LOVERING, J. (1995) Creating discourses rather than jobs; the crisis in the cities and the transition fantasies of the intellectuals and policy-makers in P. Healey, S. Cameron, S. Davoudi, S. Graham and A. Madani (Eds) Managing Cities; The New Urban Context, pp 109-126. Chichester, Wiley.

MACLARAN, A. (1993) Dublin: The Making of a Capital. Belhaven: London.

MACLARAN, A. (1996a) Private sector residential development in central Dublin', in P. Drudy and A. MacLaran (Eds) Dublin: Economic and Social Trends-Volume 2, pp 20-42. Centre for Urban \& Regional Studies: Trinity College Dublin.

MACLARAN, A. (1996b) Office development in Dublin and the tax incentive areas, Irish Geography, 29, pp 49-54.

MACLARAN, A. (1999) Inner Dublin: change and development' in J. Killen and A. MacLaran (eds) Dublin: Contemporary Trends and Issues for the Twenty-First Century, pp 21-35. Geography Society of Ireland: Special Publication 11. 
MACLARAN, A. and FLOYD, D. (1996) A Report on the Recent Residential Developments in Central Dublin. Dublin: Centre for Urban \& Regional Studies: Trinity College Dublin.

MACLARAN, A., MACLARAN, M. and WILLIAMS, B. (1994) Residential Development as an Engine for Inner City Renewal in Dublin: Commentary and Statistical Appendices. Centre for Urban \& Regional Studies: Trinity College Dublin.

MACLARAN, A. WILLIAMS, B., EMERSON, H., FLOYD, M., PUNCH, M., BREW, A. and SMITH, E. (1995) Residential Development in Central Dublin: a Survey of Current Occupiers. Centre for Urban \& Regional Studies: Trinity College Dublin.

MACLARAN, A., O'CONNELL, R. and LYSTER, D. (1999) HOK Offices 1999. Hamilton Osborne King: Dublin.

McCARTY, J. (1998) Dublin's Temple Bar-A case study of culture-led regeneration, European Planning Studies, 6, pp 271-281.

$\mathrm{M}^{\mathrm{c}} \mathrm{GUIRK}$, P.M. (1992) Perspectives of the Nature and Role of Planning in Dublin. Unpublished Ph.d. Thesis, Department of Geography: Trinity College Dublin.

$M^{\mathrm{c}}$ GUIRK, P.M. (1994) 'Economic restructuring and the realignment of the urban planning system: the case of Dublin', Urban Studies, 31, pp 289-307.

MㄷUIRK, P.M. (2000) Power and policy networks in urban governance: local government and property-led regeneration in Dublin, Urban Studies, 37, IN PRESS

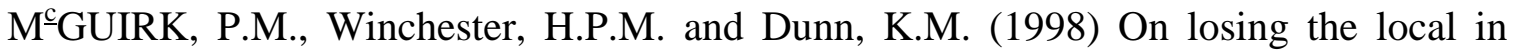
responding to urban decline: the Honeysuckle redevelopment, New South Wales, in T. Hall and P. Hubbard (Eds) The Entrepreneurial City: Politics of Regime and Representation John Wiley and Sons: Chicester, pp107-129

MALONE, P. (1996), Dublin: motive, image and reality in the Custom House Docks, in P. Malone (Ed) City, Capital and Water, pp 65-89. London: Routledge. 
MAYER, M. (1994) Post-fordist city politics in A. Amin (Ed) Post-Fordism: a Reader, pp 317-338 London:Blackwell.

MONTGOMERY, J. (1995) The story of Temple Bar: creating Dublin's cultural quarter, Planning Practice and Research, 10, pp 101-110

NEWMAN, P. and THORNLEY, A. (1996) Urban Planning in Europe: International Competition, National Systems and Planning Projects, Routledge: London.

NEWMAN, P. and THORNLEY, A. (1997) Fragmentation and centralisation in the governance of London: influencing the urban policy and planning agenda, Urban Studies , 34, pp 967-988.

PAINTER, J. (1997)Regulation, regime and practice in urban politics in M. Lauria (ed) Reconstructing Urban Regime Theory: Regulating Urban Politics in a Global Economy. Sage:Thousand Oaks, California, pp 122-143

PAINTER, J. (1998)Entrepreneurs are made, not born: learning and urban regimes in the production of entrepreneurial cities in T. Hall and P. Hubbard (Eds) The Entrepreneurial City: Politics of Regime and Representation John Wiley and Sons: Chicester, pp 259-275

PECK, J. (1995) Moving and shaking: business elites, state localism and urban privatism, Progress in Human Geography , 19, pp 16-46.

PECK, J., TICKELL, A. (1994) Searching for a new institutional fix: the after-fordist crisis and the global-local disorder in A. Amin (Ed) Post-Fordism: A Reader. Oxford: Blackwell, pp 280-316

RACO, M. (1998) Assessing 'institutional thickness' in the local context: a comparison of Cardiff and Sheffield, Environment and Planning A, 30, pp 975-996.

RHODES, R. (1988) Beyond Whitehall and Westminister: the Sub-Central Government of Britain, Unwin Hyman: London. 
RYDIN, Y. (1998) The enabling local state and urban development: resources, rhetoric and planning in east London, Urban Studies, 35, pp 175-191.

SANDERCOCK, L. (1998) Towards Cosmopolis. Chichester, Wiley and Sons.

SHAW, K. and ROBINSON, F. (1998) Learning from experience? Reflections on two decades of British urban policy, Town Planning Review, 69, pp 49-63.

SMYTH, H. (1994) Marketing the City : the Role of Flagship Developments in Urban Regeneration. London: E \& FN Spon.

STEWART, M. (1994) Between Whitehall and Town Hall: the realignment of urban regeneration policy in England, Policy and Politics , 22, pp 266-277.

STOKER, G. (1991) The Politics of Local Government, Macmillan: London.

STOKER, G. and YOUNG, J. (1993) Cities in the 1990s, Longman: London.

TICKELL, A. and PECK, J. (1996) The return of the Manchester man: men's words and men's deeds in the remaking of the local state, Transactions of the Institute of British Geographers, 21, pp 595-616.

TUROK, I. (1992) Property-led regeneration: panacea or placebo, Environment and Planning A, 24, pp 361-381.

WILKS-HEEG, S. (1996) Urban experiments limited revisited: urban policy comes full circle, Urban Studies, 33, pp 1263-1279.

WILLIAMS B. and MACLARAN, A. (1996) Incentive areas for urban renewal in P.Drudy and A. MacLaran (Eds) Dublin: Economic and Social Trends-Volume 2, pp. 43-46. Centre for Urban and Regional Studies: Trinity College Dublin.

WINTER, I. and BROOKE, T. (1993) Urban planning and the entrepreneurial state: the view from Victoria, Australia, Environment and Planning C, 11, pp 262 - 278. 


\section{FIGURE 1}

Map of location of designated areas 
TABLE 1

The three dominant elements of the Integrated Area Plan approach

\begin{tabular}{|l|l|}
\hline HOLISM & $\begin{array}{l}\text { - target managing and facilitating integrated } \\
\text { physical, social, economic and environmental } \\
\text { development rather than focusing on physical } \\
\text { development and environmental } \\
\text { improvement }\end{array}$ \\
\hline LOCALISM & $\begin{array}{l}\text { - a mid-level of planning between detailed } \\
\text { development control and abstract objectives } \\
\text { of a city development plan } \\
\text { focus attention on translating broad } \\
\text { planning objectives into locally-focused } \\
\text { implementation strategies }\end{array}$ \\
\hline SECTORAL INTEGRATION & $\begin{array}{l}\text { - provide a local government facilitated } \\
\text { framework for bringing together public, } \\
\text { private and community sector input into the } \\
\text { collaborative generation, funding and } \\
\text { implementation of strategies to achieve } \\
\text { holistic development } \\
\text { - involves co-ordination of all local authority } \\
\text { services to the locality and co-ordination of } \\
\text { cross-sectoral partnerships geared towards } \\
\text { achieving planning objectives }\end{array}$ \\
\hline
\end{tabular}


Joel Phipps

Carfax Publishing

Taylor and Francis Ltd

5 Barton Land

UK

5.4 .01

Dear Joel

Please find enclosed the corrected proofs, signed Agreement to Publish form and offprints order form referring to the article

Changing approaches to urban planning in an 'entrepreneurial city': the case of Dublin by Pauline $\mathrm{M}^{\mathrm{c}} \mathrm{G}$ Guirk and Andrew MacLaran.

We look forward to seeing the article in print

Yours sincerely

Pauline $\mathrm{M}^{\mathrm{c}}$ Guirk 